\title{
CARVALHO, Marília Pinto de (Org.). Diferenças e Desigualdades na Escola. Campinas: Papirus, 2012. 192 p.
}

Tatiana Avila Loges

Doutoranda na linha de pesquisa Sociologia da Educação da FEUSP, com Mestrado em educação e integrante do grupo de pesquisa Estudos de Gênero, Educação e Cultura Sexual -EdGES, desde 2011.
O livro “Diferenças e desigualdades na escola” (2012), organizado por Marília Pinto de Carvalho, apresenta uma coletânea de resultados de pesquisas, e foi desenvolvido a partir de uma parceria entre três universidades - a Universidade Federal de Mato Grosso (UFMT), a Universidade Federal Fluminense (UFF) e a Universidade de São Paulo (USP), com o apoio do Programa Nacional de Cooperação Acadêmica da Capes.

A coletânea analisada oferece uma visão abrangente de vários aspectos implicados nas diferenças percebidas nos meios escolares. O primeiro capítulo, Literatura e educação para as relações raciais, de Candida Soares da Costa, busca compreender o cumprimento da Lei 10.639, com ênfase na literatura, como possibilidade de inclusão dos conteúdos de história, cultura afro-brasileira e africana no currículo escolar. A autora realizou a pesquisa numa escola pública do Estado de Mato Grosso e analisou os discursos de três professores do Ensino Médio. Segundo ela, assim como a Arte, a Literatura pode ser entendida e usada como um dos eixos fundamentais para a construção de um currículo escolar que aborde as relações raciais.

Andréia Botelho de Rezende e Marília Pinto de Carvalho, em Formas de ser menino negro: articulações entre gênero, raça e educação escolar, buscam entender como os processos sociais se estabelecem na trajetória escolar de um grupo de alunos negros. Em seus estudos, as autoras perceberam que os alunos negros, pertencentes a famílias de baixo poder aquisitivo, recebem mais conceitos negativos durante 0 processo de escolarização para os quais, consequentemente, são aconselhadas atividades de recuperação. A investigação foi realizada em uma escola pública de São Paulo, na qual os 
sujeitos participantes da pesquisa eram quatro meninos negros. Adotando os conceitos de raça, gênero e masculinidade, as autoras observaram os diferentes significados de ser menino e menina para os envolvidos. A pesquisa revela a importância de se trabalhar conjuntamente as categorias raça e classe, para uma melhor análise da real situação escolar do grupo. 0 estudo também abordou temas como autoclassificação do grupo sobre a sua etnia e as percepções das professoras sobre "o perfil das boas alunas e dos alunos bonzinhos".

O capítulo Quando os jovens retornam à escola: os sentidos da EJA em seus percursos biográficos, de Mariane Brito da Costa, analisou as motivações da evasão e o retorno à escola de um grupo de oito jovens, entre a faixa etária de 15 a29 anos de idade, da segunda etapa do ensino fundamental, oferecido na modalidade educação de jovens e adultos, no Rio de Janeiro. A autora utilizou as narrativas dos alunos sobre suas experiências individuais para compreender as distintas trajetórias escolares vivenciadas pelo grupo. Merece destaque a atenção dada à singularidade dos alunos, bem como às justificativas vinculadas aos aspectos econômicos e à entrada no mercado de trabalho.

Em A vida na universidade: um estudo do cotidiano do "cotista" negro da UERJ, Patrícia Costa Pereira da Silva investiga o cotidiano acadêmico dos alunos cotistas negros. A autora ressalva a importância das políticas de ações afirmativas no Brasil principalmente para os negros. A pesquisa foi desenvolvida em dois cursos de graduação - Nutrição e Direito - e baseou-se em observações do cotidiano acadêmico dos discentes cotistas e nas entrevistas realizadas com sete alunos, que relataram situações de discriminação racial. Patrícia Costa Pereira da Silva evidenciou, em suas análises, a percepção do grupo sobre ser um aluno cotista e quais as estratégias utilizadas para superar esse obstáculo.

Em Alunas de engenharia elétrica e ciência da computação: estudar, inventar, resistir, Maria Clara Lopes Saboya analisa o ingresso e o cotidiano de um grupo de mulheres nestes dois cursos da área de exatas, numa faculdade na região metropolitana de São Paulo. 0 estudo investigou o perfil das estudantes, 42 alunas do curso de Ciência da Computação e 7 do curso de Engenharia Elétrica, totalizando 49 mulheres. As justificativas apresentadas pelo grupo, quando indagadas sobre o que as motivou à escolha dos respectivos cursos foram: facilidade com as disciplinas na área de exatas, possível ascensão econômica e social, e também, em menor número, a influência dos pais. No artigo, a autora observou os entraves presentes e as próprias reações das 
alunas para superá-los e garantirem sua permanência nos respectivos cursos, além de evidenciar que tais alunas sofrem preconceitos por uma parte dos colegas e docentes.

0 artigo 0 branco nas relações raciais construídas na escola, de Luciana Alves, discute os significados conferidos à brancura e a maneira como tais significados fornecem elementos para a construção e reprodução do racismo na escola. 0 objetivo do artigo é refletir sobre as relações raciais e principalmente sobre como a ideia de brancura influência essas relações no cotidiano escolar. A autora entrevistou 10 professores participantes de um curso de formação docente que tinha o objetivo de discutir a diversidade racial. Esses professores se autodeclararam da seguinte maneira: seis negros e quatro brancos. 0 estudo mostra as narrativas interpretativas do grupo, cheias de significados, das diversas maneiras que a brancura thes foi apresentada na escola. A autora evidencia que a brancura vista como algo natural foi construída a partir das relações de poder que se estabeleceram em nossa sociedade. 0 artigo se difere dos trabalhos sobre diversidade racial que centralizam seus estudos na representação de negros e inova ao discutir a representação de brancura presente nos livros didáticos e nos discursos históricos.

O último artigo da coletânea, Professoras do vale do Arinos: trajetórias de migração, de Lori Hack de Jesus e Maria Lúcia Rodrigues Müller, observa o processo de migração de dezesseis docentes que residem na cidade de Juara, em Mato Grosso. Os autores buscam perceber os fatores implicados na decisão do grupo de migrar para a cidade. Além disso, elucidam a história da cidade, a qual está intimamente ligada aos colonos imigrantes sulistas. Dentro desse contexto, segundo as autoras, é possível conhecer algumas influências que levaram o grupo à escolha da profissão docente, e também seus posicionamentos em relação ao processo de migração.

Os sete capítulos que integram o livro tratam de diferenças e desigualdades presentes na escolarização. Trata-se de diversos trabalhos que englobam reflexões sobre as diferenças e as desigualdades presentes tanto nos ensinos fundamental, médio e superior, bem como na própria trajetória do corpo discente e docentes. Os trabalhos apresentados nessa coletânea revelam o esforço das autoras em romper com o círculo vicioso do senso comum sobre os temas tratados. 


\section{REFERÊNCIAS}

CARVALHO, M. P. (Org.). Diferenças e desigualdades na escola. 1. ed. Campinas: Papirus, 2012. v. 1. 192p.

RECEBIDO: Setembro de 2012.

APROVADO: Março de 2013. 